\title{
A Corte Constitucional da Itália e o Direito Administrativo
}

\author{
Eduardo Lobo Botelho Gualazzi \\ (Procurador do Estado. Professor Adjunto de Direito Administrativo da FADUSP)
}

\begin{abstract}
RESUMO: 1. Contribuição da Corte Constitucional da Itália para o Direito Administrativo. 2. Jurisprudência administrativa específica. 3. Recomendaçōes da Corte para cabal aplicação da Constituição Italiana, no âmbito dos Poderes Executivo e Legislativo. 4. Supremo Tribunal Federal do Brasil poderia assumir competência constitucional semelhante, mutatis mutandis.
\end{abstract}

RIASSUNTO: 1. Contribuzione della Corte Costituzionale d'Italia nei confronti del Diritto Amministrativo. 2. Giurisprudenza amministrativa particolare. 3. Raccomendazioni della Corte per il totale adempimento della Costituzione Italiana, nell'interno dei Poteri Esecutivo e Legislativo. 4. Supremo Tribunale Federale del Brasile potrebbe avere competenza costituzionale assomigliata, mutatis mutandis.

UNITERMOS: 1. Corte Constitucional. 2. Direito Administrativo. 3. Jurisprudência administrativa. 4. Supremo Tribunal Federal.

Desde algum tempo, inclusive por vivermos o momento da reconstitucionalização do Brasil, acentuou-se o interesse pela Corte Constitucional da Itália, tema que obviamente já inspirou, na Itália, a publicação de alentadas monografias, bem como, no Brasil, de alguns artigos, esparsos. Nesta síntese, buscaremos apenas resumir e noticiar um aspecto específico, particularíssimo, das atividades da Corte Constitucional da Itália, consistente na contribuição daquela Corte para o Direito Administrativo, na Itália.

Desde 1956, quando se iniciou o funcionamento normal da Corte Constitucional da Itália, foram objeto de julgamento e decisões daquela Corte várias normas jurídico-positivas do Direito Italiano, atinentes a matérias administrativas, a saber: a) reforma regional; b) reformas à legislação comunal e provinciaí; c) reformas relativas ao status jurídico dos funcionários públicos; d) reforma sanitária, em dois momentos (1969 e 1978), com a instituição do Serviço Sanitário Nacional; e) alterações na disciplina urbanística; f) reformas procedimentais da lei de 1865 , sobre desapropriaçōes por utilidade pública; g) reforma das instituição públicas de assistência e beneficência (sentença fundamental da Corte Constitucional, n- 174, de 1981); h) reformas no setor da justiça administrativa (disciplina orgânica dos recursos administrativos, instituição dos órgāos de primeiro grau, regulamentação do status jurídico dos Magistrados da magistratura administrativa ordinária etc.). 
Vários pronunciamentos da Corte Constitucional da Itália contribuiram à individuação dos elementos de que se pode deduzir a natureza de um ato administrativo (Sentença no 103/1957), à distinção entre ato administrativo normativo e ato administrativo especial (Sentenças n-s 4/1958, n- 56/1959, nº 26/1961 e nº 134/1963), à distinção entre controle sobre os atos e controles sobre os órgāos (Sentença no 24/1957) e à determinação dos característicos próprios dos entes de Direito Público (Sentença nº 12/1959).

De alto relevo foram os pronunciamentos da Corte Constitucional da Itália a respeito da discricionariedade administrativa (Sentenças $\mathrm{n}^{\circ} \mathrm{s}$ 105/1967, $32 / 1969,21 / 1973$ e 114/1982), tendo salientado que ocorre distinguir entre o conteúdo da norma legal que consente discricionariedade (tema exclusivo da lei) e a aplicação concreta da discricionariedade (a critério de administradores públicos), no sentido de que a errônea aplicação não pode comportar a inconstitucionalidade da norma, quando for formulada de modo a não oferecer vício de inconstitucionalidade e, especialmente, a não apresentar-se como "irracional e privada de limites". Afirmou a Corte que a discricionariedade é necessária para a atividade administrativa, porquanto as leis e particularmente a Constituição não podem prever e disciplinar todas as mutáveis situações de fato, nem graduar em abstrato e com antecipação as limitaçōes antepostas ao exercício dos direitos (Sentença no 2/1956). Ainda segundo a Corte Constitucional da Itália, em tema de discricionariedade administrativa, é necessário que a norma não contenha indeterminação ou excessiva largueza (Sentenças $n^{\circ}$ s 1 e 2 , de 1956).

Por outro lado, várias vezes a Corte Constitucional da Itália insistiu sobre a necessidade de motivação expressa nos atos administrativos que envolvam limitaçōes aos direitos do cidadāo (Sentença no 12/1965, entre outras), bem como sobre que o conceito de imparcialidade abrange o de moralidade da atividade administrativa (Sentença $n^{\circ}$ 89/1971).

Reconheceu a Corte Constitucional da Itália, outrossim, que a ausência de contraditório, num procedimento administrativo, nāo é inconstitucional (Sentença no 32/1974), assim como, sob o perfil constitucional, nem mesmo é necessário que seja assegurada a garantia da defesa, que se limita apenas aos procedimentos de caráter jurisdicional e àqueles conexos e preordenados a uma atividade jurisdicional (Sentenças n's 200/1970, 10/1971 e 122/1974).

Ademais, notabilizaram-se os arestos da Corte Constitucional da Itália, no tocante à relação de emprego público. Ab initio, a Corte dedicou-se a analisar os característicos próprios da relaçāo de emprego público e, particularmente, as diferenças entre este tipo de relação e a do emprego privado. A Corte decidiu que a diferença de regime jurídico entre ambas as relaçōes jurídicas não viola o princípio de igualdade, em vista de que a relação privatística rege-se por leis 
predominantemente econômicas, a que se adequa a vontade dos contraentes (Sentença $n^{\circ}$ 88/1963), tendo salientado posteriormente que, malgrado as notáveis alterações na legislação, que reduziram a diversidade entre ambas as relações, as duas situaçōes não são idênticas porque na relação de emprego público ocorre um interesse público, a garantir o bom andamento de ofícios e serviços, segundo as Sentenças nos 49/1976 e 90/1984. De qualquer modo, a Corte Constitucional da Itália sempre deliberou no sentido de reduzir, até os limites possíveis, as diferenças entre as relaçōes de emprego público e privado, sobretudo no tocante ao aspecto remuneratório (Sentenças nㅇs 5/1970, 219/1975, $46 / 1983$ e 90/1984). Neste quadro colocam-se alguns pronunciamentos atinentes ao sistema pensionístico e, mais genericamente, ao estipêndio acordado aos funcionários públicos no momento da cessação do serviço, entre as quais ocorre recordar os arestos que reconheceram o direito a pensão a ex-funcionários atingidos por interdição perpétua aos ofícios públicos (Sentença no 3/1966), bem como àqueles que se demitiram voluntariamente do emprego público (Sentença $\mathrm{n}^{\mathrm{o}}$ 191/1974).

De fundamental importância foi a sentença no 55 , de 1968, que atribuiu à noção de expropriação um significado particular, no sentido de abranger os "vínculos urbanísticos indefinidos" no tempo. Este aresto propiciou e inspirou o legislador italiano à edição da Lei no 1187, de 1968.

Este rol de arestos da Corte Constitucional da Itália nāo é exaustivo, mas apenas exemplificativo, porquanto buscou condensar os aspectos mais significativos do Direito Administrativo Italiano que sofreram a direta influência da Corte Constitucional da Itália.

Como qualquer órgão judiciário do Brasil ou da Itália, a Corte Constitucional da Itália somente pronuncia-se, apenas judica quando provocada por parte interessada, segundo o vetusto brocardo "ne procedat judex ex officio". Porém, ao judicar no âmbito de suas altas competências constitucionais, a Corte Constitucional da Itália não se limita exclusivamente a dirimir lides concretas, mediante a correta interpretação do Direito Constitucional Positivo da Itália, mas principalmente a dirigir a toda a Administração Pública Italiana e aos Poderes Executivo e Legislativo da Itália recomendaçōes específicas, de lege lata et de lege ferenda, a respeito do necessário cumprimento, in concreto, da Constituição da República Italiana. Em outros termos, a Corte Constitucional da Itália não obriga, juridicamente, os Poderes Legislativo ou Executivo da Itália a legislarem do modo como a Corte considere mais adequado e conveniente, mas adverte e recomenda, de motu proprio, àqueles Poderes, quais as providências Iegislativas ou administrativas que repute indispensáveis para a cabal observância da Constituição da Itália, no âmbito das litispendencias que a Corte é suscitada a julgar, sob o crivo da constitucionalidade. Em visia de tais recomendaçōes da Corte Constitucional da Itália, várias vezes o legislador italiano criou Direito novo, Direito Objetivo, ou derrogou Direito Positivo, anterior à 
Constituição Italiana, de 1947. Em suma, a Corte Constitucional da Itália, em matéria constitucional, exerce um pápel ativo e positivo, no seio dos outros Poderes da República Italiana, no sentido de pressionar e estimular a adoção de atos administrativos ou atos de administração, bem como a legiferação (criação de Direito novo ou derrogação do vigente), para aperfeiçoar a correta aplicação da Constituição Italiana no âmbito de todos os serviços públicos da Itália, atinentes aos três Poderes.

Mutatis mutandis, poder-se-ia cogitar, no Brasil, a respeito de atribuir-se ao nosso Supremo Tribunal Federal, na próxima Constituição, a faculdade de dirigir recomendações aos Poderes Legislativo e Executivo, de lege lata ou de lege ferenda, exclusivamente no tocante ao cabal cumprimento da própria Constituição, para aperfeiçoar-lhe a aplicação na área administrativa ou para o oportuno preenchimento de lacunas legislativas, no âmbito do jus costituendo. Escusado relembrar que tais recomendações do Supremo Tribunal Federal seriam eventualmente emanadas, a critério exclusivo da Alta Corte, no âmbito dos casos concretos, das litispendências específicas, submetidas ao crivo de constitucionalidade do Pretório máximo da Federação Brasileira.

Roma, 15 de maio de 1988. 